\title{
Ny digital opplæring i omsorg ved livets slutt
}

Kommunene mangler helsefagarbeidere med kompetanse innen lindrende behandling og omsor g ved livets slutt. En ny dig ital opplæringspakke er utviklet for å heve kompetansen.

\section{Forfattere}

\section{Lucie Furulund}

Fakultetsrådgiver

Høgskolen i Innlandet Fakultet for helse- og sosialvitenskap

\section{Mette Løhren}

Leder ekstern virksomhet

Hogskolen i Innlandet Ringgold standard institution - Fakultet for helse- og sosialvitenskap

\section{Tore Litleré Rydgren}

Seniorrådgiver

IT-seksjon Hogskolen i Innlandet Ringgold standard institution - Fakultet for helse- og sosialfag

\section{Nøkkelord}

\section{Utdanning Samhandling Pedagogikk Palliasjon Kommunehelsetjeneste}

Sykepleien 2018 106(65377)(e-65377)

DOI: https://doi.org/10.4220/Sykepleiens.2018.65377

\section{HOVEDBUDSKAP}

Opplæringen er nettbasert med filmer, lenker, caser, interaktive tester og studieheftet. Individuelt arbeid kombineres med gruppesamlinger ledet av mentor. Mentorer er sykepleiere/helsefagarbeidere med kompetanse i lindrende behandling. Faginnholdet er grunnleggende kunnskaper og oppgaver knyttet til behandling og omsorg til pasienter med kort forventet levetid. Målgruppen er helsefagarbeidere og ansatte uten formell kompetanse i kommunehelsetjenesten. Kan være aktuell for nyutdannede sykepleiere. 
Høgskolen i Innlandet, i samarbeid med

Utviklingssenter for sykehjem og hjemmetjenester

(USHT) og ressursnettverket for palliasjon i Hedmark, har på oppdrag fra Helsedirektoratet utarbeidet en digital opplæringspakke innen lindrende behandling og omsorg ved livets slutt. Regionalt kompetansesenter for lindrende behandling i Helse Sør-Øst har kvalitetssikret det faglige innholdet.

Opplæringspakken ble testet i pilotprosjektet i flere kommuner i Norge i perioden 2016-2017. Målgruppen for opplæringen er helsefagarbeidere og ansatte uten formell kompetanse som jobber $\mathrm{i}$

kommunehelsetjenesten som for eksempel i sykehjem, i hjemmebaserte tjenester eller i tjenester for funksjonshemmede. Erfaringer fra pilotperioden viser at opplæringspakken kan være aktuell for nyutdannede sykepleiere.

\section{三 «Opplæringspakken kan være aktuell for nyutdannede sykepleiere.»}

Det faglige innholdet beskriver grunnleggende kunnskaper i lindrende behandling og omsorg ved livets slutt. Det legges vekt på helsefagarbeiderens oppgaver knyttet til behandling og omsorg til pasienter med kort forventet levetid. Pasienter som har behov for lindring av plagsomme symptomer i senere faser av sykdomsforløpet helt frem til livet er avsluttet. Opplæringspakkens materiale består av filmer, lenker, caser, interaktive tester og studieheftet. Opplæringen er nettbasert og kombinerer individuelt arbeid med gruppesamlinger i læringsgrupper. Gruppesamlingene ledes av en mentor. Mentor er en sykepleier eller en helsefagarbeider med relevant fagskoleutdanning og kompetanse i lindrende behandling og omsorg.

Mentorene får veilederopplæring. 
Den digitale opplæringspakken i lindrende behandling og omsorg ved livets slutt skiller seg fra de tradisjonelle kompetansehevende tiltak og fra de tradisjonelle e-læringskurs med sin fleksibilitet, lokal tilpassing, digitale og pedagogiske løsninger.

\section{Bakgrunn}

Kompetansehevende tiltak innen lindrende behandling og omsorg har over lengre tid vært et stort satsingsområde i Norge. Selv om det har vist seg at ulike kompetansehevende tiltak har ført til kompetanseheving på arbeidsplassen, er det fortsatt viktig å utvikle kompetansen innen fagfeltet i de kommunale helse- og omsorgstjenestene.

Samhandlingsreformen legger blant annet opp til å tilby helsetjenestene nærmere der folk bor (1). Dette har gitt kommunene flere oppgaver som medfører at de må utvikle spesialiserte og sterke nok fagmiljøer til å ivareta pasientenes ulike behov. Kommunene mangler helsefagarbeidere med kompetanse innen lindrende behandling og omsorg. I tillegg er en stor andel av ansatte i kommunale helsetjenester uten formell kompetanse (2).

\section{Hensikt}

Målet er å heve kompetansen innen fagfeltet lindrende behandling og omsorg ved livets slutt hos ansatte i kommunale helse- og omsorgstjenester (3). Målgruppen for kompetanseutvikling er i utgangspunktet helsefagarbeidere og ansatte uten formell kompetanse. I Kvalifikasjonsrammeverket for livslang læring (4) benyttes begrepet «kandidater» om deltagerne i kompetanseutviklingen, derfor benyttes dette begrepet videre i artikkelen om målgruppen.

Erfaringer fra pilotperioden viser at temaene i opplæringspakken også er aktuelle for nyutdannede sykepleiere i kommunale helse- og omsorgstjenester.

\section{Forventet kompetanse}


Målet er at kandidatene videreutvikler sin kompetanse og at pasientene får lindrende behandling og omsorg av høy kvalitet. De som har gjennomgått opplæringen skal også kunne gi pårørende i ulike aldre en opplevelse av nødvendig støtte og anerkjennelse.

Det faglige innholdet i opplæringspakken bygger på føringer i Nasjonalt handlingsprogram med retningslinjer for palliasjon i kreftomsorgen (5) og i Rapport om tilbudet til personer med behov for lindrende behandling og omsorg mot livets slutt $-\AA$ skape liv til dagene (6). Kunnskap relatert til de største diagnosegruppene som blant annet kreft, kols og progredierende nevrologiske sykdommer, samt kunnskap relatert til eldre personer med behov for lindrende behandling er vektlagt i denne opplæringspakken.

\section{三 «Det er ingen eksamen.»}

I den digitale opplæringspakken er det er ingen eksamen. Kandidatene kan teste sine kunnskaper og forståelse gjennom interaktive tester. I gruppesamlinger med mentor gjennomføres refleksjon. Refleksjonen er relatert til kandidatenes egne eksempler fra sin praksis eller på de ulike case fra den digitale opplæringspakken. Det er refleksjon over egen praksis som bidrar til videreutvikling av kompetanse (7). I læringsgruppene diskuteres det nye tiltak som de kan prøve ut i sin praksis på egen arbeidsplass.

\section{Faglig innhold}

Opplæringspakken inneholder opplæringsmateriale som vektlegger helsefagarbeiderens oppgaver og ansvar knyttet til behandling og omsorg for pasienter som mottar lindrende behandling og omsorg, og omsorg for deres pårørende. 
Opplæringspakken beskriver begreper innen lindrende behandling og omsorg og gir grunnleggende kunnskaper om hva som er relevant å kartlegge, observere og iverksette av tiltak ved de mest vanlige symptomer hos pasienter med behov for lindrende behandling og omsorg ved livets slutt. Opplæringen knyttes til pasienter med de fire største kreftdiagnosene, til pasienter med kronisk obstruktiv lungesykdom (kols), langtkommen hjertesykdom og nevrologiske sykdommer som amyotrofisk lateral sklerose (ALS), multippel sklerose (MS) og Parkinsons sykdom. Den eldre pasientens spesielle utfordringer vektlegges. Kandidatene får kjennskap til symptomkartlegging ved hjelp av ESAS-skjema, numerisk smerteskala og kroppskart. Det gis praktiske råd om væsketilførsel og ernæring. Videre får kandidatene kjennskap til hvordan pasienter og pårørende med bakgrunn i ulike kulturer ser på alvorlig uhelbredelig sykdom og på døden.

Kandidatene vil få forståelse for pårørendes reaksjoner, innsikt i hvordan man kan kommunisere med pårørende for å kartlegge deres situasjon og gi dem målrettet støtte. Det blir lagt vekt på å lære kandidatene hvordan de skal ta hånd om barn som er pårørende. Ved livets slutt oppstår ofte medisinske, etiske og juridisk krevende problemstillinger. Kandidatene får kjennskap til forberedende samtaler med pasient og pårørende og tiltaksplan for døende. Når kandidatene har gjennomført opplæringen, skal de ha utviklet en etisk grunnholdning som profesjonell yrkesutøver.

\section{Tre bærende elementer}

Møte mellom mennesker + digitale læringspakker = kompetanseheving

Den digitale opplæringspakken er nettbasert, dynamisk, fleksibel og praksisnær. Den bygger på tre bærende elementer:

- Digital læringsplattform 
- Mentorer

- Grupper

Valg av moderne e-læringsplattform kan være en avgjørende suksessfaktor for læring. Det at kandidatene er i læringssituasjonen mellom samlingene fremmer læring. E-læringsplattformen spiller her en rolle for å oppnå et jevnt læringstrykk. Teknologien skal fungere som et støtteverktøy under opplæringen. Det bygger på forståelse og kunnskap om de tre likeverdige forholdene: teknologi, pedagogikk og faginnhold (8). Morgendagens kandidater forventer å kunne lære når de selv ønsker det og gjerne ved hjelp av egne mobiltelefoner. Den digitale læringsplattformen skal kunne fungere på tvers av Android og Apple-støtte, på alle digitale enheter som mobil, nettbrett eller pc.

\section{三 «Morgendagens kandidater forventer å kunne lære når de selv ønsker det og gjerne ved hjelp av egne mobiltelefoner.»}

Det legges opp til individuelt arbeid på nett og erfaringsutveksling i læringsgrupper på jobb.

Gruppene ledes av en mentor. Da vi utviklet læringsdesignet, la vi vekt på mentorrollen. Mentorene har en avgjørende funksjon for å sikre de gode læringsprosessene både mellom og på samlingene. Forskning viser at mentorbaserte, arbeidsbaserte læringsgrupper gir læring og bidrar til mindre frafall fra opplæringen (9). Mentorene får opplæring i veiledning og i veilederrollen. Mentorene følger opp kandidatene og sikrer framdrift og kvalitet i læringsarbeidet. De gir faglig og teknisk støtte. Det er bærekraftig for arbeidsplassen at opplæringsløp «ruller og går» og at mentorene selvrekrutteres fra opplæringsgrupper. Selvrekrutterte mentorer kan bidra til økt læringstrykk, motivasjon, inspirasjon og faglig engasjement. 
Det er hensiktsmessig at læringsgruppene møter mentor etter hvert emne, for eksempel en gang hver tredje uke. Det anbefales at hver gruppesamling varer i cirka to timer. Gjennom det individuelle arbeidet og arbeidet i læringsgruppene med mål og spørsmål som kan brukes i refleksjonsarbeidet, skapes det en bevissthet rundt egen og arbeidsplassens praksisutøvelse. Reflekterende veiledning er en læringsstrategi som legger vekt på den likeverdige samtalen mellom profesjonelle yrkesutøvere (10). Kandidatene kan reflektere rundt mulige forbedringsområder i eget arbeid og de kan utvikle forståelse for å arbeide kunnskapsbasert (11).

\section{Læringsinnhold}

Fagstoffet er organisert i fire fagemner:

1. Lindrende behandling og omsorg - den profesjonelle omsorgsyteren

\section{Diagnoser, symptomer og symptomlindring}

3. Pårørende til pasienter som mottar lindrende behandling og omsorg

\section{Lindrende behandling og omsorg til døende} pasienter

Figur 1. Bilde av den digitale læringsplattformen

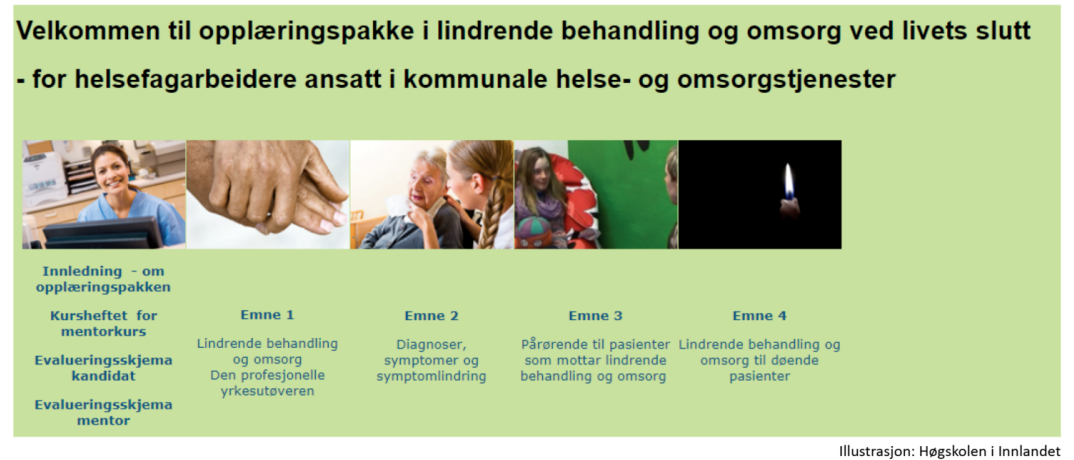


- En digital utgave med tekst, bilder, filmer, lenker, caser, refleksjonsspørsmål, interaktive tester og kildeliste.

- Studiehefte. Dette er en papirutgave som inneholder fagstoff med grunnleggende kunnskaper i lindrende behandling og omsorg.

Den digitale utgaven og studieheftet utfyller hverandre.

\section{Omfang og organisering}

Gjennomføring av ett emne har et arbeidsomfang på i gjennomsnitt ti timer. Tidsbruk er tre til fire uker per emne. Varighet på opplæringspakken er cirka fem måneder sammenhengende opplæring. Det er hensiktsmessig å begynne med emne 1. Kommunene og kandidatene kan selv bestemme opplæringspakkens omfang, rekkefølge av emner og valg av læringsmaterialet. Kommunene rekrutterer selv ansatte som har behov for opplæring og deler de i læringsgrupper. Det bør være inntil seks ansatte i hver gruppe. Minst femti prosent bør være helsefagarbeidere. Med hensyn til små kommuner kan læringsgrupper etableres på tvers av kommuner.

Figur 2. Organisering

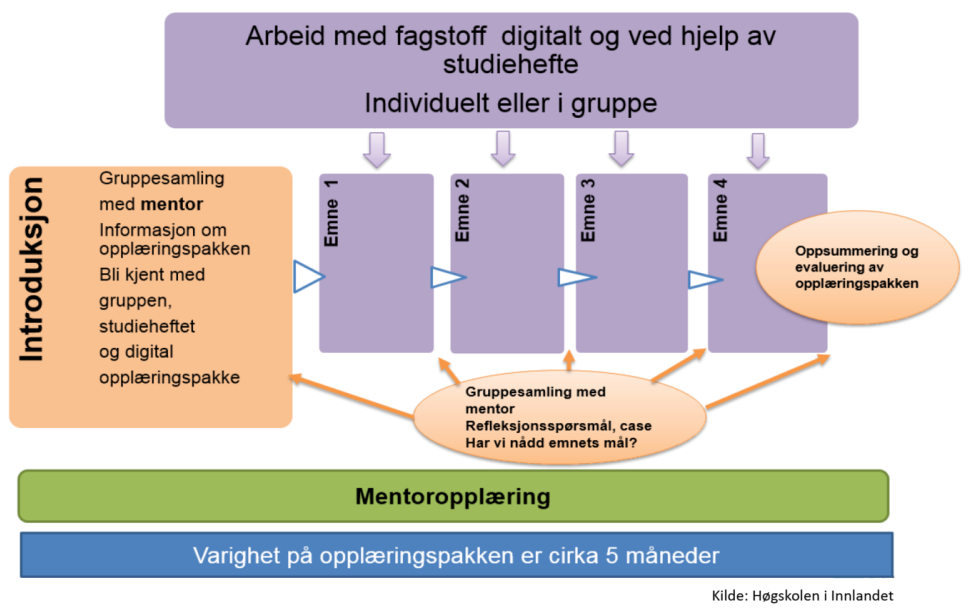

\section{Utprøvingen av} opplæringspakken 
I perioden 2016-2017 ble det gjennomført to pilotprosjekter som en del av utviklingsarbeidet. I første fase deltok kommunene Trysil, Lørenskog og Bærum. I denne fasen koordinerte Høgskolen i Innlandet både den faglige tilretteleggingen, mentoropplæringen og det administrative og tekniske arbeidet. I fase to ønsket helsedirektoratet å teste ut rollen til USHT og ressursykepleienettverket som faglige koordinatorer og opplæringsansvarlige for mentorene. Fase to ble gjennomført under veiledning fra høgskolens prosjektleder og med teknisk administrativ støtte fra høgskolen. Det var USHT i Buskerud og USHT i Hedmark som deltok i fase to. Til sammen har over 100 kandidater gjennomført den digitale opplæringspakken. Om lag 25 mentorer har gjennomført mentoropplæringen.

Høgskolen i Innlandet sto for evaluering av pilotprosjektet. Kandidater, mentorer, kommuner, USHT og ressursykepleiernettverket ga tilbakemeldinger. Høgskolen reviderte både faginnholdet og de digitale løsningene i opplæringspakken. Det regionale kompetansesenteret for lindrende behandling i Helse-Sørøst og helsedirektoratet har ytterligere kvalitetssikret det faglige innholdet.

\section{Tilbakemeldinger fra pilotene}

Evalueringene pekte på opplæringspakkens

fleksibilitet, praksisnærhet og konseptet som et godt tilrettelagt kompetansehevende tiltak. Betydningen av at opplæringspakken kombinerer faginnhold med digitale løsninger, mentoroppfølging og læring på arbeidsplassen var en suksess. Det var lite frafall og de fleste kandidatene gjennomførte opplæringsløpet. Læringsmodellen skiller seg derfor fra andre elæringsprogrammer.

\section{三 «Det var lite frafall og de fleste kandidatene gjennomførte opplæringsløpet.»}




\section{Nasjonal modell}

Høgskolen i Innlandet har utviklet og pilotert en digital opplæringspakke i lindrende behandling og omsorg ved livets slutt som nå gjennomføres som en nasjonal modell i hele landet. Opplæringen kombinerer en nettbasert fagopplæring med lokal gjennomføring.

Pilotering har pågått over tid og har nå funnet en form som er relevant og gjennomførbar for helsesektoren. Evalueringene fra pilotprosjektet viser at kandidatene får mulighet til å videreutvikle sin egen kompetanse i lindrende omsorg, som er tilpasset og relevant for den arbeidsplassen de jobber på. Kombinasjon av en nettbasert opplæringsmodell og lokale mentorer som følger opp kandidatene underveis i opplæringsløpet, er en avgjørende faktor for at kompetanseheving oppleves som relevant og av høy faglig kvalitet. Den tette oppfølgingen av lokale mentorer og faglig tilpassede emner har bidratt til at kandidatene fullfører opplæringsløpet, noe som igjen hever kvaliteten i utøvelse av helsetjenestene til pasienter som mottar lindrende behandling og omsorg ved livets slutt og til de pårørende. Den digitale opplæringspakken i lindrende behandling og omsorg ved livets slutt skiller seg fra de tradisjonelle kompetansehevende tiltak og fra de tradisjonelle e-læringskurs med sin fleksibilitet, tilpassing, digitale og pedagogiske løsninger.

\section{三 «Opplæringen kombinerer en nettbasert fagopplæring med lokal gjennomføring.»}

Helsedirektoratet ga i 2017 tilskudd til åtte kommuner til å gjennomføre den digitale opplæringspakken:

Drammen, Hamar, Bergen, Sør-Varanger, Oslo, Sandefjord, Vestvågøy og Ålesund. USHT i Hedmark og USHT i Buskerud har ansvar for koordinering av mentoropplæringen (3). Helsedirektoratet ønsker å ta i bruk opplæringspakken i et undervisningsopplegg som inngår i et større kompetansehevingsprosjekt, Trygghetsstandard i sykehjem (12). 
Høgskolen i Innlandet har muligheter for å tilby den

digitale opplæringspakken direkte til kommunene, etter nærmere avtale mellom partene. Opplæringen som ble gjennomført i Kvinesdal kommune er et eksempel og det står flere kommuner på bestillingslisten.

\section{Referanser:}

1. Regjeringen. Samhandlingsreformen informasjon om ikraftsetting av lov om kommunale helse- og omsorgstjenester [Internett]. Oslo; 2011 [sitert; 26.01.2018]. Tilgjengelig fra:

https://www.regjeringen.no/no/dokumenter/samhandlingsreformeninformas...

2. Helsedirektoratet. Årsrapport 2016.

Kompetanse og personell i helse - og

omsorgstjenesten i kommunene Status 2016 for

Kompetanseløft 2020. Oslo; 2016. IS-2684 [sitert;

26.01.2018]. Tilgjengelig fra:

https://helsedirektoratet.no/Documents/Godkjenning\%20og\%20autorisasjon/\%...

3. Regjeringen. Nasjonalt

kvalifikasjonsrammeverk for livslang læring (NKR)

[Internett]. Oslo; 2011 [sitert; 26.01.2018].

Tilgjengelig fra:

https://www.regjeringen.no/globalassets/upload/kd/vedlegg/kompetanse/nkr...

4. Helsedirektoratet. Tilskudd fra

helsedirektoratet [Internett]. Oslo; 2018 [sitert;

26.01.2018]. Tilgjengelig fra:

https://helsedirektoratet.no/tilskudd/kompetansehevende-

tiltak-for-lindr...

5. Helsedirektoratet. Nasjonalt handlingsprogram

med retningslinjer for palliasjon i kreftomsorgen

[Internett]. Oslo; 2015. IS-2285 [sitert; 26.01.2018].

Tilgjengelig fra:

https://helsedirektoratet.no/retningslinjer/nasjonalt-

handlingsprogram-m... 
6. Helsedirektoratet. Rapport om tilbudet til personer med behov for lindrende behandling og omsorg mot livets slutt - å skape liv til dagene [Internett]. Oslo; 2015. IS-2278 [sitert; 26.01.2018]. Tilgjengelig fra:

https://www.regjeringen.no/contentassets/a4b45c8f57e741bdbb3bfb32c6b9ef4...

7. Schön DA. The reflective practitioner: How professionals think in action. Aldershot: Avebury; 1991.

8. Kristensen A. Design av studium med bruk av teknologi. Synkron. 2016 februar;(1):16-17.

9. Valen K, Ytrehus S, Grov EK. Tilnærminger anvendt i nettverksgrupper for kompetanseutvikling i det palliative fagfeltet. Vård i Norden. 2011; 31(4):49.

10. Lingås LG, Olsen KR, Eik LT. Pedagogisk veiledning. Oslo: Gyldendal akademisk; 2013.

11. Helsebiblioteket. Refleksjon over egen praksis. Oslo: Helsebiblioteket;2016 [sitert; 26.01.2018] Tilgjengelig fra: http://www.helsebiblioteket.no/kunnskapsbasertpraksis

12. Helsedirektoratet. Trygghetsstandard i sykehjem. Oslo: Helsedirektoratet; 2018. Tilgjengelig fra: https://helsedirektoratet.no/sykehjem-oghjemmetjenester/trygghetsstanda...(nedlastet 26.01.2018). 